\title{
La Aventura Mítica en "La Flor del Aire"' de Gabriela Mistral
}

Pocos han sido los críticos que han destacado la multiplicidad de elementos arquetípicos implícitos en la poesía de Gabriela Mistral. Uno de los que ha sugerido una interpretación más honda, pero al mismo tiempo limitada, ha sido Gaston von dem Bussche ${ }^{1}$ quien advierte estos rasgos predominantemente en relación con la expresión del mundo americano:

Su majestuoso valor americanista reside en esta vivencia constante de significaciones míticas y consumadoras a través de las cosas y hombres de nuestro continente. Sale de su ámbito personal al ámbito del mundo y su canto se hace cósmico como consecuencia de su religiosidad primitiva. También son cósmicos los mitos de las religiones antiguas. (p. 10)

Esta hipótesis, que ha no sido probada ni continuada por otros ensayistas, es indudablemente válida, pero limitada. A nuestro juicio, las estructuras míticas o las imágenes arquetípicas se encuentran tanto en los poemas que cantan América o 10 primitivo como en aquellos que hablan de sus propias experiencias personales. En un ensayo anterior, hicimos evidente cómo la experiencia de los celos adquiere en el poema "Balada" una conformación mítica a través de la aureolización mítico-cósmica de los amantes. ${ }^{2}$ Ahora intentaremos mostrar que el poema "La flor del aire" se estructura sobre la base de elementos de la aventura mítica y que contiene a la vez una serie de imágenes arquetípicas, algunas de ellas asociadas con los ritos de iniciación. ${ }^{3}$

Los críticos, sin embargo, han concedido escasa importancia a los vínculos arquetípicos, movidos especialmente por una declaración de la propia Gabriela, quien, en nota al texto, explicó su sentido. Dijo que este poema era su "aventura con la poesía." 'Esta autointerpretación, obviamente válida, ha desviado a los pocos críticos que se han preocupado del poema. Se le ha concedido mayor importancia a la teoría poética implícita

1 Gaston von dem Bussche, Visión de una poesia (Santiago, Chile: Ediciones AUCH, Universitaria, 1957).

2 "Balada o la mitificación de la anécdota amorosa en Gabriela Mistral", Revista Chilena de literatura.

3 Hemos desarrollado extensamente un análisis e interpretación de los constituyentes de la aventura mítica y sus relaciones con los ritos de iniciación en nuestro libro La aventura mitica de la aventura del béroe (Barcelona: Planeta, 1973). 
que a los contenidos poéticos.

El estudioso antes citado se refiere al pasar al texto que aquí nos interesa:

Del mismo modo, resulta reveladorísimo la oposición entre La flor del aire, que es el mito mistraliano sobre la creación poética, y el Arte poética de Neruda. Para éste, la creación poética se define en un 'movimiento sin tregua,/ y un nombre confuso', mientras que para la Mistral, la poesía aparece como una Deidad implacable a la que no puede hacer sino servir... (Visión de una poesia, p. 63)

la tragicidad de la Mistral aparece como el sentimiento de la inevitable prisión en el tiempo, cuya puerta sólo abrirá la muerte, pero cierta de que la Poesía puede entreabrirla para respirar el aire 'real', una poesía de sentido, realización y estabilización. (Visión de una poesía, p. 63)

Sin duda que puede establecerse un sistema de interpretación en que lo mentado en el poema adquiere sentido en el plano de la teoría poética y de su historia personal con la poesía. Creemos no obstante que lo más significativo del mismo surge de las múltiples resonancias que origina el misterio que aureola el encuentro de la hablante con la dama de la pradera y la serie de acciones que suceden a dicho encuentro. La emotividad no se explica por el paralelismo de las imágenes y algunas dimensiones de las relaciones de Gabriela con la poesía. Esta emana de los significados implícitos y la potencia alusiva de las imágenes, las cuales se enraízan en las imágenes arquetípicas.

\section{LA FLOR DEL AIRE}

1 Yo la encontré por mi destino,

2 de pie a mitad de la pradera,

3 gobernadora del que pase,

4 del que le hable y que la vea.

5 Y ella me dijo: - "Sube al monte.

6 Yo nunca dejo la pradera,

7 y me cortas las flores blancas

8 como nieves, duras y tiernas'.

9 Me subí a la ácida montaña,

10 busqué las flores donde albean,

11 entre las rocas existiendo

12 medio-dormidas y despiertas.

13 Cuando bajé, con carga mía,

14 la hallé a mitad de la pradera,

15 y fui cubriéndola frenética,

16 con un torrente de azucenas.

$17 \mathrm{Y}$ sin mirarse la blancura,

18 ella me dijo: " "Tú acarrea

19 ahora sólo flores rojas.

20 Yo no puedo pasar la pradera".

21 Trepé las peñas con el venado, 
22 y busqué flores de demencia,

23 las que rojean y parecen

24 que de rojez vivan y mueran.

25 Cuando bajé se las fui dando

26 con un temblor feliz de ofrenda,

27 y ella se puso como el agua

28 que en ciervo herido se ensangrienta.

29 Pero mirándome, sonámbula,

30 me dijo: "Sube y acarrea

31 las amarillas, las amarillas.

32 Yo nunca dejo la pradera".

33 Subí derecho a la montaña

34 y me busqué las flores densas,

35 color de sol y de azafranes,

36 recién nacidas y ya eternas.

37 Al encontrarla, como siempre,

38 a la mitad de la pradera,

39 segunda vez yo fui cubriéndola,

40 y la dejé como las eras.

41 Y todavía loca de oro,

42 me dijo: "'Súbete, mi sierva,

43 y cortarás las sin color,

44 ni azafranadas ni bermejas".

45 "Las que yo amo por recuerdo

46 de la Leonora y la Ligeia,

47 color del Sueño y de los sueños.

48 Yo soy Mujer de la pradera".

49 Me fui ganando la montaña,

50 ahora negra como Medea,

51 sin tajada de resplandores,

52 como una gruta vaga y cierta.

53 Ellas no estaban en las ramas,

54 ellas no abrían en las piedras

55 y las corté del aire dulce,

56 tijereteándolo ligera.

57 Me las corté como si fuese

58 la cortadora que está ciega.

59 Corté de un aire y de otro aire,

60 tomando el aire por mi selva...

61 Cuando bajé de la montaña

62 y fui buscándome a la reina, 


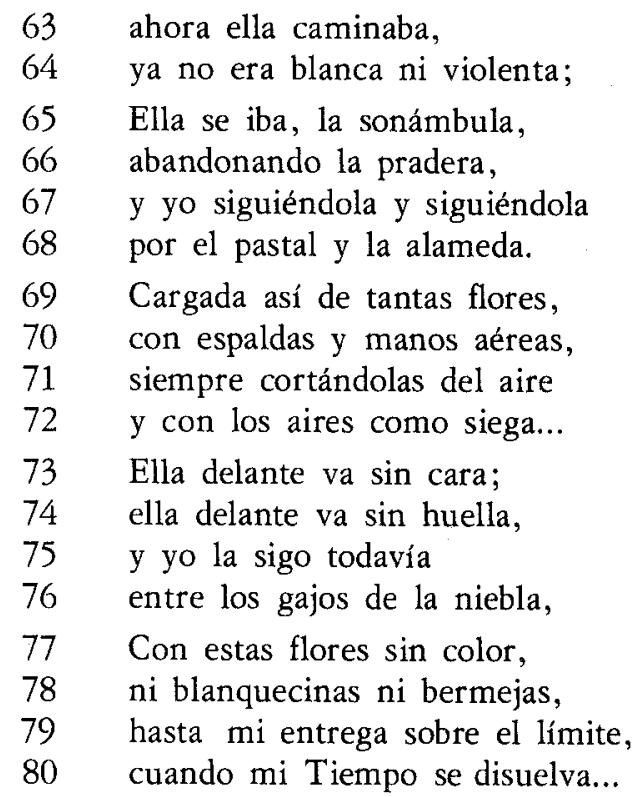

Un examen ingenuo de la historia revela de inmediato una serie de rasgos que la asocian con la estructura mítica de la aventura del héroe y con instancias de los procesos iniciáticos. Los más evidentes son el encuentro con el personaje misterioso, el ascenso a la montaña, el reiterado retorno con el botín, la serie de entregas a la sacerdotisa y la aceptación final de la mujer misteriosa del servicio indefinido de la hablante.

Examinemos con mayor cuidado tanto la composición del poema como el carácter mitificante de los elementos del mismo. A mi juicio, la clave radica en el hecho de describir un proceso de iniciación, en el cual tanto los motivos básicos como secundarios alcanzan una dimensión mitificada. E1 poema trata de la iniciación de la poetisa, de su ingreso progresivo a una zona de poder, a la que identifica simbólicamente con la poesía, o un tipo de poesía.

Al aceptar esta hipótesis no puede sorprender el proceso de mitificación que se advierte desde la primera estrofa, y que se manifiesta tanto en el espacio en que acontece la acción como en las características de los personajes.

En cuanto al espacio, son dos los elementos claves: la pradera y la montaña, ambos presentados de manera típica del espacio iniciático. Las interpretaciones del espacio sagrado que ha proporcionado Mircea Eliade explican parcialmente las connotaciones de misterio. Eliade apunta que un elemento esencial del mundo en la concepción sagrada es el habitar en el centro del mundo, el axis mundi. ${ }^{4}$

El axis mundino se trata del espacio geométrico, sino de un espacio existencial y sagrado que presenta una estructura radicalmente distinta, que es suceptible de una 
infinidad de rupturas y, por lo tanto de comunicaciones con lo trascendente.

Es indispensable interpretar el espacio en cuyo centro se encuentra el personaje que adquirirá progresivamente una dimensión sobrenatural. La pradera se asocia con las aguas. De este modo, implica la naturaleza en su estado de potencia creadora. No creemos que la pradera de Gabriela Mistral puede identificarse con la interpretación dada por Gaston Bachelard y aludida por Cirlot. ${ }^{5}$

El mitema del axis mundi se complementa perfectamente con la otra dimensión del espacio nombrado al comenzar el poema: la montaña. También ha indicado Mircea Eliade el carácter mágico-religioso de la montaña como Bachelard y el contorno positivo afectivamente que se asocia con lo que denomina la poética de la verticalidad. Eliade dice que la montaña al ubicarse en el centro del mundo entra en armonía con la necesidad de ascenso, el cual a su vez se vincula con la creencia en la Montaña cósmica.

Todo ascender en el mundo del mito es un aproximarse a las fuentes o a las cercanías de la divinidad, de lo sagrado: "el hombre de las sociedades tradicionales no podía vivir más que en un espacio 'abierto' hacia lo alto.' (Lo sagrado y lo profano, p. 48) La montaña, además, constituye uno de los espacios tradicionales en cuanto a la comunicación con la divinidad o el lugar donde se va a buscar el elixir sagrado o el mensaje del dios.

En este espacio se produce el encuentro de la protagonista con un personaje que progresivamente va adquiriendo una dimensión sobrenatural.

La estrofa inicial se centra en la motivación del encuentro y en la presentación del nuevo personaje. La primera mención crea una imagen de paisaje de pintura gótica en el que ella emerge solitaria. Desde el centro de la pradera parece ejercer control sobre los viandantes. El efecto es crear un personaje misterioso, de gran poder, que en su aislamiento y soledad, adquiere una figura magnificada. Aunque se le nombra "gobernadora" la impresión que produce es la de un ser sobrenatural, que ejerce poderoso dominio sobre ciertos seres, pues no se le hace visible a cualquier viajero, sino sólo a algunos que poseen condiciones, los que podemos llamar los elegidos.

Además de la estructura misma del poema, que lo vincula con el proceso iniciático, lo más significativo -desde el punto de vista del mito- son las características del personaje con quien se encuentra. Obviamente se asocia con la diosa de la tradición de la aventura heroica. Campbell, en El béroe de las mil caras ${ }^{6}$ describe sintéticamente lo que será desarrollado por Neumann en The Great Mother y The Origins and History of Consciousness:

La Dama de la Casa del Sueño es una figura familiar en el cuento de hadas y en el mito. Ya hemos hablado de ella en las formas de Brunilda y la Bella Durmiente. Es

5 Para Bachelard:

"La prairie, la prairie oeuvre de la rivière es, à elle seule, pour certaines âmes un thème de la tristesse. Dans la vèritable prairie des âmes, il ne croit que des asphodeles. Les vents n'y trouvent pas les arbres chanteurs, mais seulement les vagues silencieuses de l'uniform verdure." ( $L$ 'eau et les rèves. Essai sur l'imagination de la matière. Paris: Librairie Jose Corti, 1942) Esta interpretación de Bachelard es válida en el contexto de Eleonora de Edgar Allan Poe, sin embargo, no calza perfectamente en el caso del poema que comentamos.

6 Joseph Campbell, El héroe de las mil caras (México: FCE, 1959). 
el modelo de todos los modelos de belleza, la réplica de todo deseo, la meta que otorga la dicha a la búsqueda terrena y no terrena de los héroes. Es madre, hermana, amante, esposa. Todo lo que sea se ha anhelado en el mundo, todo lo que ha parecido promesa de júbilo, es una premonición de su existencia, ya sea en la profundidad de los sueños, o en las ciudades y bosques del mundo. Porque ella es la encarnación de la promesa de la perfección; la seguridad que tiene el alma de que al final de su exilio en un mundo de inadecuaciones organizadas, la felicidad que una vez se conoció será conocida de nuevo: la madre confortante, nutridora, la 'buena madre' -joven y bella, que nos fue conocida y que probamos en el pasado más remoto. El tiempo la hizo desaparecer y sin embargo existe, como quien duerme en la eternidad, en el fondo de un mar intemporal. (El béroe de las mil caras, p. 105)

Si proyectamos estas ideas al plano simbólico de la poesía la interpretación sumaria sería la siguiente: la hablante le ofrendó a la Poesía diversas clases de poemas. Por fin encontró aquéllos que proporcionara una nueva vida a la Poesía. Desde entonces se dedica a servirla con humildad y devoción.

Esta interpretación, sin embargo, no satisface ni explica la multiplicidad de emociones, evocaciones y asociaciones que derivan de la lectura. Estas sólo se explican a través de la resonancia simbólica-mítica de los constituyentes del poema y de la aventura.

La iniciación propiamente tal en el poema no se constituye por $u n$ viaje, en el cual el iniciante experimenta las diversas aventuras. En nuestro caso, se conforma por varias instancias, cuatro viajes, cada uno de ellos con elementos propios de la aventura. Naturalmente los cuatro viajes no son emotivamente yuxtapuestos. Por el contrario, constituyen una continuidad, una gradación en la que se complementan progresivamente, de manera que cada uno va acercando más a la protagonista al logro de su deseo. Cada uno tiene los rasgos fundamentales de la aventura mítica: 1) Recibe el llamado y la orden del ser superior; 2) El viaje en busca del elíxir, el cual cambia en cada caso, y el ascenso a la montaña; 3) El retorno, que implica el descenso de la montaña; 4) La entrega de la ofrenda obtenida y el servicio a la divinidad.

La estructura formal del poema se organiza del siguiente modo: La estrofa primera corresponde al encuentro; la segunda, tercera y cuarta, al primer viaje; el segundo viaje es cubierto en las estrofas quinta, sexta y séptima; el tercer viaje se presenta en la octava, novena y décima; el cuarto y último aparece en las estrofas undécima, duodécima, décimatercera, décimacuarta, décimaquinta y décimasexta. Las cuatro estrofas finales corresponden a la unión de los dos personajes.

Oelker Link, que ha dedicado un buen estudio a este poema, explica la organización del siguiente modo : 7

Después de la aprehensión de los tres 'viajes simbólicos' que para el poeta significan la tensión de búsqueda y experiencia de iniciación -debemos destacar que el poeta nos los dice en tres grupos de cada vez tres estrofas, semejantes en su significación: la primera con el 'mandato', la segunda con la 'búsqueda' y la

7 Dieter Oelker Link, "La actitud mítica, poética-religiosa, en las Historias de Loca de Gabriela Mistral," Atenea, año XLV; tomo CLXX, núm. 421-422, (Julio-Diciembre, 1968), pp. 79-123. 
tercera con el 'regreso' al punto inicial-, nos aproximamos al núcleo del poema, a las cinco estrofas ya señaladas por el título, y en las cuales sucede la consagración.

(p. 107)

Creemos que Oelker capta bien la clave; sin embargo en su ensayo no lo desarrolla o no infiere las consecuencias del planteamiento.

En el primer viaje, como indica Oelker, la aventura se inicia con la orden, que en este caso, implica subir al monte y volver con flores blancas.

Ya hemos comentado brevemente el significado del monte en la tradición mítica y poética. Es el lugar en que posiblemente se encuentra el elixir mágico, la poción maravillosa que ha de salvar a la princesa de los cuentos infantiles. La orden viene con unas explicaciones que enriquecen la caracterización general antes mencionada, al mismo tiempo que revelan una limitación del personaje sobrenatural ("Yo nunca dejo la pradera"). Esta extraña limitación puede entenderse en varias posibilidades. Como personaje divino permanece sólo en el espacio sagrado. Desde otra perspectiva, es la diosa que requiere de ofrendas, para las cuales necesita discípulos y discípulas que se sacrifiquen por ella. El no dejar la pradera bien puede ser un acto limitador o una decisión personal. Al final del poema, descubrimos que en realidad la búsqueda tiene por finalidad proporcionarle el objeto que le permitirá salir de la pradera. En otras palabras, este personaje sobrenatural hace uso de la poetisa, de la hablante, para que la libere de su limitación, en el fondo es la búsqueda de su propia libertad. Necesita del elíxir mágico de que habla Campbell, pero ella no lo puede salir a buscar. Esta interpretación explica el tono de tristeza implícito en el verso 6: "Yo nunca dejo la pradera.." El parlamento continúa con "y me cortas las flores blancas / como nieves, duras y tiernas." (vv. 7-8) Expresión que implica la perspectiva, naturalmente, de la dama y no de la hablante.

Las flores en la tradición representan la fragilidad, la fugacidad de las cosas, la primavera y la belleza. Según Cirlot también "Por su forma la flor es una imagen del centroy , por consiguiente, una imagen arquetípica del alma." 8

En cuanto al color, Cora Santandreu, que hace registro de los colores usados por Gabriela Mistral, recuerda que "blanca, albo, es para la Mistral símbolo de pureza, de candidez, de virtud, de recogimiento místico, de lo no mancillado, de la belleza panteísta, de la serenidad, de lo sublime, de la bondad del alma, de la inmortalidad." "9

Dieter Oelker Link, que parte de las ideas de Cirlot antes citadas, afirma que "las blancas nos dicen purificación e iniciación(...) a la vez que insinúan éxtasis y participación", ("La actitud...", p. 106).

Una de las características de un análisis funcional debe ser el no considerar la información que proporciona la tradición sin el contexto particular del poema. En este caso, si bien es verdad que las citas insisten en la dimensión de la pureza, lo que sorprende es la comparación que sigue a la mención del color, por cuanto determina el matiz que surgió de la imaginación mistraliana: "como nieves, duras y tiernas." Tanto la expresión "nieves", indicio de frialdad al mismo tiempo que pureza, como la paradoja "duras y

${ }^{8}$ Juan Cirlot,Diccionario de simbolos tradicionales (Barcelona: Luis Miracle, editor, 1958).

9 Cora Santandreu, Aspectos del estilo de Gabriela Mistral/(Santiago,Chile:Ediciones AUCH,1957), p. 84. 
tiernas" expresanuna dimensión insatisfactoria de la blancura de las flores.

Si estas son las características de "lo buscado"' tampoco las de la montaña son de todo positivas. En la aventura es tradicional que el héroe experimente una serie de peligros. En este caso, no se narran los peligros sino las dimensiones negativas del espacio de la aventura. La orden comienza con la expresión "sube al monte", que se asocia con las viejas tradiciones miticas del ascenso a la montaña. La hablante, cual otro Moisés, asciende a la montaña. Esta es calificada con la sinestesia "ácida", que pareciera indicar tanto la dureza, lo desértico, como las dificultades que tuvo en el ascenso. Por último, el lugar donde se encuentran las flores:

\section{busqué las flores donde albean, entre las rocas existiendo medio-dormidas y despiertas.}

Con lo cual indica la rareza de las flores, es decir, no surgen en su medio natural sino en un espacio árido en el que no tienen una existencia cómoda, por ello existen en estado de transición, "medio-dornidas y despiertas."

En el plano poético, pareciera querer indicar que este tipo de poesía es frágil, a punto de perecer.

Triunfa en su búsqueda y al retornar -motivo del descenso de la montaña- encuentra nuevamente a la diosa en el medio de la pradera, el axis mundi, y le ofrece "frenética" el tributo de su hallazgo. Cubre, como cubren los devotos a la virgen con flores. La mención de las azucenas es inmensamente significativa.

Las azucenas son el símbolo de la pureza. En Chile, además, se asocian con la adoración de la Virgen María y con la primera comunión de las niñas. Asociación que involucra en nuestra interpretación, con más claridad aún, la adoración que la iniciante lleva a cabo.La diosa-la poesía, tenemos que suponer- es cual la Virgen en el mes de diciembre: cubierta de azucenas. La diferencia, sin embargo,con el rito católico viene de la expresión frenética. Por cuanto, el servicio a la Virgen de las niñas que hacen la primera comunión -también iniciantes en el rito católico- es amable y controlado. La iniciante del poema se entrega con frenesi a su servicio poético.

El segundo viaje (estrofas V, VI, y VII) reitera la misma estructura del primero: la orden, el retorno. Pese al entusiasmo de la iniciante, la sacerdotisa no se satisface con la ofrenda y requiere ahora "flores rojas". Insiste en su limitación: "Yo no puedo pasar la pradera"' (v. 20).

Oelker dice que "las flores rojas, más que pasión, nos significan sangre derramada en el sacrificio, vida ofrecida" (p. 106). Por su parte, Cora Santandreu, apoyándose en el fragmento que comentamos, afirma que la poetisa asigna al " tojo el contenido vivencial de la locura." (p. 178) Anteriormente había señalado:

La poetisa no escatima el hacer resaltar mediante diferentes símbolos la gama del rojo, en consonancia con el ardiente tono emocional de la poesía; porque el rojo es también para Gabriela pasión. (p. 78)

Aunque en apariencia ambas interpretaciones se contradicen, en el fondo no es así, ya que cada una apunta a planos distintos en la dualidad simbólica del poema. Cora San- 
tandreu a la poesía y Oelker a la posibilidad arquetípica. El verso 22 confirma la exégesis de Santandreu: "y busqué flores de demencia." Habria que entender esta nueva ofrenda, primero, casi en un plano de interpretación directa de las palabras de los versos. Es decir, en oposición a las primeras -blancas,- éstas presentan una dimensión diferente. Frente a la pureza de las otras, podemos pensar de la infancia, éstas representan la pasión, el sentimiento intensificado. Si las proyectamos a la vida de Gabriela, aún podría pensarse que implican el sufrimiento, la entrega al sentimiento intensificado. Estas como las primeras se determinan con una paradoja, que se asocia con la famosa de Santa Teresa, "de rojez vivan y mueran."

El viaje en este caso es más arduo que en la primera instancia. La expresión "trepé", parece indicar un ascenso escarpado y la mención al venado puede implicar la dificultad de la altura. Al mismo tiempo, el venado asume la función de acompañante en su aventura, con lo cual el viaje se aureola con las asociaciones que la imaginación y la tradición conceden al venado, especialmente cuando al final vuelve al motivo con la mención del "ciervo." El matiz es sugerente.

Veamos, en primer término, el simbolismo del ciervo, para luego examinar su sentido y función en el fragmento que comentamos. Cirlot se refiere a varias posibilidades, algunas de las cuales son significativas para nuestro análisis.

Su sentido simbólico se halla ligado al del árbol de la vida, por la semejanza de su cornamenta con las ramas arbóreas. También es el símbolo de la renovación y crecimiento cíclicos. (Dicc., p. 133)

En diversas culturas asiáticas y de la América precolombina, el ciervo es símbolo de la renovación, a causa de los brotes de sus cuernos. (Dicc., p. 133-134)

En el periodo medieval, en Occidente, la vía de la soledad y de la pureza fue simbolizada con frecuencia por el ciervo, que en algunos emblemas aparece con la cruz entre la cornamenta (completando así la relación árbol-cruz y árbolcornamenta. También fue considerado como animal simbólico de la elevación. (Dicc., p. 134)

Por lo tanto, podemos interpretar las menciones al venado, en primer término, como indicio de la altura -necesidad de agilidad- a la cual hubo de ascender para llegar a las flores que ha ido a buscar. Pero, a la vez la selección del venado es reveladora de la clase de espiritualidad con que se ha lanzado a la aventura. ${ }^{10}$ No se trata, por ejemplo, del cabro, que también seria indicio de agilidad y de subir a lugares escarpados. El venado manifiesta la pureza y la espiritualidad. "1

10 Dámaso Alonso ha destacado el carácter espiritual del ciervo, especialmente por supuesto, en sus versiones a lo divino: "Esta imagen del amor profano es llevada en seguida, atrevidamente, a las religiones del amor divino: Dios es como un ciervo, como una garza, perseguida y cobrada por el amor del hombre." ("La caza de amor es altaneria,"' De los siglos oscuros al de oro (Madrid: Editorial Gredos, 1958), p. 260.)

11 Cirlot insiste en este carácter espiritual: " Entre los griegos y romanos, ya se reconocen ciertas cualidades 'misticas' at ciefvo, exagerándose por proyección psíquica. Entre estas condiciones figura la atribución de una sabiduría instintiva para el reconocimiento de las plantas medicinales, por lo que la mayor parte de antiguos bestiarios dicen: 'El ciervo conoce el Dictamo.' Parte de su prestigio lo debe el ciervo a sus características físicas ; su belleza, su gracia y agilidad. Por su papel de mensajero de los dioses, el ciervo puede considerarse como la antitesis del macho cabrio.' (Diccionario de simbolos tradicionales,(Barcelona: Luis Miracle, editor, 1958), p. 134. 
El retorno representa una vez más la ofrenda, el servicio:

Cuando bajé se las fui dando como un temblor feliz de ofrenda.

Presenciamos, entonces, la metamorfosis extraordinariamente curiosa de la diosa: y ella se puso como el agua que en ciervo herido se ensangrienta.

En estos versos encontramos el cruce de varias tradiciones. Dámaso Alonso recuerda el cruce del motivo del ciervo con el de la fuente de amor:

El tema del ciervo herido que va al agua y el de la caza de amorse enlazan a veces tambiẻn (a lo divino) en la poesía culta. (Dámaso Alonso, "La caza de amor...", p. 261, nota 13)

En el plano de lo tradicional cita la hermosa estrofa del Cancionero da Vaticana, núm. $7911^{12}$ :

Tal vai o meu amigo
con amor que lh'eu dei
come cervo ferido
de monteiro del-rei.

Las flores rojas transforman el color de la diosa de blanca a roja, con la cual pareciera indicar que de diosa de la pureza se transforma en diosa de la pasión y del sacrificio. Lo importante, desde el punto de vista con que interpretamos el texto, es que esta acción por una serie de asociaciones adquiere más evidentemente un carácter ritual, de sacrificio y ofrenda. En cuanto a las tradiciones que se cruzan, podemos señalar los motivos del ciervo berido, el ciervo en el agua, la fuente del amor al que acuden los ciervos, la sangre que enrojece el agua,el cual a su vez puede asociarse con el de la tórtola que enturbia el agua. ${ }^{13}$

Los matices mítico-religiosos se hacen más evidentes si se piensa el ciervo en la asociación de árbol de la vida, por lo tanto en el fondo símbolo de Cristo o de la divinidad. Si se acepta esta dirección interpretativa, en el fondo la escena descrita es la divinización o aureolización divinizante de la diosa, que se bautiza en el río al igual que Cristo. Sin embargo, la dimensión que el contexto sugiere no llega a estas alturas. Lo que es innegable es que las imágenes crean una atmósfera no terrenal y asociable con la divinidad o el mundo del bestiario mítico.

\footnotetext{
${ }^{12}$ El carácter mitificador del cruce de estos dos motivos está muy bien señalado por Eugenio Asensio: “La sugestión erótica de la fuente se debe, no tanto a que sea lugar de enamorados, como a simbolismos elementales de la humanidad. Estas conjunciones simbólicas-que la escuela de Jung llama arquetípicas y supone, sin razón suficiente, heredadas por la vía fisiológica-pululan en el folclore. Ellas dan su secreto hechizo a las cantigas de Pero Meogo, donde el ciervo del monte revuelve la fontana fría. En el siglo XV guardaban aún para el pueblo su nimbo mitológico y no habían aun sido suplantadas por racionalizaciones, como la del cántaro roto, o escenas realistas, como la de Leonor yendo a la fuente." (Poetica y realidad en el cancionero peninsular de la Edad Media (Madrid: Gredos, 1957), pp. 260-261).

13 Sobre este último motivo, véase María Rosa Lida. "Transmisión de temas grecolatinos en la poesía lírica espanfola,"' RFH, I (1939), pp. 20-63. Sobre la tórtola, que se baña en agua que ella misma ensucia, Marcel Bataillon, "La tortolica de Fontefrida y del Cantico espiritual," NRFH, VII, núm. 1-2 (Enero-Junio, 1953, pp. 291-306).
} 
La aventura se reitera. Por tercera vez la iniciante recibe la orden de subir a la montaña. El primer verso de la serie implica una diferencia con respecto a las dos ocasiones anteriores. En el primer y segundo viaje la hablante asume con relativa naturalidad la insatisfacción de la señora de la llanura. Ahora, luego de los versos de exaltación semimística, comienza con un adverbio adversativo, "pero", que pareciera indicar la sorpresa de que aún no esté satisfecha. Califica, además, su actitud o comportamiento. La señora está como embriagada con lo que ha recibido - "sonámbula" - y a su nueva solicitud es parte de su delirio de entusiasmo, de su enajenamiento. Extasis que se manifiesta además en la orden, ya que insiste en la calificación de las flores, signo de embriaguez afectiva:

me dijo: "sube y acarrea

las amarillas, las amarillas.

Esta reiteración intensifica la urgencia, premura o ansia. El último verso de la misma estrofa -"Yo nunca dejo la pradera" - parece un suspiro de frustración.

A propósito de las flores amarillas, Oelker, basándose en Cirlot dice:

Nos dicen la iluminación instantánea de los orígenes y acontecimientos, paso de lo exterior a lo interior, de la circunsferencia al centro, del espacio y tiempo a lo supratempóreo y supraespacial. (p. 106)

Por su parte, Cora Santandreu afirma que el amarillo es " poco frecuente en la obra de la Mistral; prefiere el símbolo oro, sol, azafrán, ámbar, aromos, etc." (p. 95) Sin embargo, señala dos significados: "Amarillo es más bien para la poetisa la expresión de lo mustio y de lo marchito." (p. 96) "Amarillo es para la Mistral la huella del tiempo sobre los seres y las cosas." (p. 96)

Ninguna de las dos citas revelan algo realmente significativo para interpretar los versos que comentamos. Por lo tanto, es preciso desplazar el enfoque desde el parlamento de la diosa hacia la interpretación que de ellas da la hablante: "flores densas, color de sol y de azafranes.' 'El énfasis más que en el amarillo está en el color del sol. Las flores de que habla son doradas. Cirlot al hablar de las flores señala que su color determina los rasgos, aunque lo común es que son un símbolo de la obra del sol. Agrega que "el carácter solar se refuerza en las flores anaranjadas y amarillas.' (Dicc., p. 204)

Las flores que la iniciante va a buscar en el tercer viaje se asocian predominantemente con el sol, el que obviamente tiene una multiplicidad de posibilidades simbólicas.

Examinemos otros rasgos de las flores en el poema antes de plantear una hipótesis. Las de este viaje, al igual que en los dos viajes anteriores, poseen una existencia dinámica, es decir, un modo de ser en transición. En este caso, "recién nacidas y ya eternas", como en los anteriores fue: "como nieves, duras y eternas," "de rojez vivan y mueran."

La expresión del tercer viaje implica una mayor ternura, el énfasis se da en el "recién nacidas", pero sin embargo son eternas. Con lo cual se acentúa la asociación con el amanecer y con el sol.

¿Qué significan en el plano de la poesía? Posiblemente la búsquedade un modo de hacer poético que tome temas universales.

La estrofa final de esta serie reitera lo acontecido en la estrofa IV, con pequeños 
matices sugeridores de diferencia. Indica el carácter habitual - "como siempre", y luego que repite la acción de la primera ocasión - "segunda vez yo fui cubriéndola"- explica que queda "como las eras". Expresión que insiste en el color dorado y que por lo tanto la asocia una vez más con el sol. La expresión eras implica la plenitud de la naturaleza, es el esplendor de la naturaleza fecundizada por el sol.

Pese a esta serie de entregas, la diosa se mantiene insatisfecha. La serie de ofrendas que ha recibido aun no la satisfacen. Por el contrario, parecen llenarla de entusiasmo y embriaguez para seguir exigiendo más a la iniciante. Se ha ido transformando progresivamente en una diosa del sacrificio a quien sus devotos le entregan ofrendas, pero que nunca la satisfacen. La tragedia, sin embargo, en este caso surge de la limitación que tiene. Al parecer las exige no gratuitamente sino con la esperanza de que llegue alguna que sea capaz de salvarla, de liberarla. Ha reiterado en cada ocasión que no puede abandonar la pradera.

En la primera ocasión dijo "Yo nunca dejo la pradera"' con lo cual daba la impresión de que su limitación no era sino un acto voluntario. En la segunda oportunidad, verso 20, su "Yo no puedo pasar de la pradera," implica un acto involuntario, una imposibilidad. En la tercera ocasión, reitera el "Yo nunca dejo la pradera,", pero ahora ya no tiene el mismo matiz que en la primera oportunidad. Ahora, es un especie de lamento.

De este modo llegamos al cuarto viaje, cuya importancia se advierte formalmente primero en la mayor extensión y en el quiebre con respecto a la estructura formal seguida en los casos anteriores.

La orden se expresa ahora en dos estrofas y con una confesión más amplia. La aventura-viaje y el hallazgo del "vellocino" se describe en tres estrofas. El descenso, como en los casos anteriores, en una estrofa.

Podemos interpretar esta serie como el triunfo. Los tres viajes anteriores aun cuando terminaban éxitosamente porque encontraba las flores encargadas, no resolvían el problema de la diosa. Oelker califica esta sección como la "consagración": las cinco estrofas siguientes constituyen "el núcleo del poema, a las cinco estrofas ya señaladas por el título, y en las cuales sucede la consagración." (p. 107)

Analicemos más cuidadosamente las estrofas XI a XVI. Ahora la dama, casi enloquecida, enajenada de entusiasmo, "loca de oro", exige un nuevo ascenso. Esta vez en busca de las flores sin color, "ni azafradas ni bermejas." El parlamento hace evidente ya la relación entre ambas. La diosa afirma que es su "sierva", es decir, la sirve humilde y entregadamente.

La "'diosa"' explicita más su relación con las nuevas flores:

Las que yo amo, por recuerdo

de la Leonora y la Ligeia, color del Sueño y de los sueños. (vv, 45-47)

Oelker remite con la mención de los dos personajes femeninos a Bürger y Poe. ${ }^{14}$

14 "'Recuérdese la Leonore de Gotfried August Bürger y la Ligeia de Allan Poe." (p. 108) Y agrega: "Ella es por el recuerdo de lo que ama, por el recuerdo de la Leonora, de la fidelidad más allá del límite, y el de la Ligeia que, como fantasía de perfección sobrenatural e ideal visionario, triunfa sobre el tiempo que devora la carne de los mortales."' (pp. 107-108) 
Consideremos que es más plausible pensar que ambas referencias vienen de los cuentos fantásticos de Poe, ya que tiene dos con los respectivos nombres de Eleonora y Ligeia. ${ }^{15}$ Hay que aceptar que los dos se complementan. Para ello, veamos en primer término, su significado en las historias del cuentista norteamericano.

El hablante ama a Eleonora en su juventud y cuyas características le hace representar la pureza y la soledad. Es su prima y vive idealmente en un mundo aislado y feliz: el "Valley of the Many-Colored Grass.' El narrador recuerda que:

Offered up a vow, to herself and to Heaven that I would never bind myself in marriage to any daughter of Earth. (p. 651)

Ligeia en cambio es "lady Ligeia", y ya no la conoce en la pureza del campo sino en la ciudad, "in some large, old decaying city near the Rhine." Ella representa la inteligencia, el intelecto; pero especialmente el amor que existe y persiste después de la muerte.

La mención de los personajes de Poe debe ser entendida como dos dimensiones complementarias: la ingenuidad y pureza de la adolescencia (Leonora) y la sabiduría y fidelidad de Ligeia. En ambos casos se trata de un compromiso total, que va más allá de los límites de la muerte. En el fondo, la alusión conlleva la entrega absoluta.

Veamos ahora el simbolismo posible de las flores. La hablante dice que son "color del Sueño y de los sueños" (verso 47) y luego agrega que son " sin color.",

Cora Santandreu se refiere a estos versos y apunta:

Elemento propulsor de creación artística que recorre vetas subterráneas, identificándose con lo telúrico, con lo cósmico y sublimado en los más geniales versos de la lengua española. (pp. 66-67)

Las flores se caracterizan más limitadamente en versos posteriores, "corté de un aire y otro aire", y explica el título del poema. Mención que de inmediato remite a la espiritualidad. Bachelard explica que todo lo que asciende -uno de cuyos motivos es el aireimplica una voluntad de elevación y espiritualidad. ${ }^{16}$ Recuerda, por ejemplo a Nieztsche para quien el aire " es la sustancia misma de nuestra libertad, la sustancia de la alegría de lo sobrehumano."' (p. 120) El mismo Bachelard hace otras referencias que se relacionan directamente con nuestro tema: "en la imaginación humana, el vuelo es una trascendencia de la grandeza.' '(p. 84)

De todo lo cual hay que inferir que el cuarto tipo de flor que la diosa requiere se asocia con la espiritualidad, la pureza y la entrega de sí misma en su servicio. En el poema, adquiere a la vez el matiz de lo inalcanzable, del sueño irrealizado, de los anhelos irrealizables. En el fondo, apunta a la entrega absoluta a lo inalcanzable. Oelker sugería que representan "el recuerdo de la máxima perfección.", (p. 108)

La aventura en sí, como corresponde al ritmo de las iniciaciones, se hace más difícil en esta oportunidad. En los casos anteriores, describió el ascenso en términos como: " $\mathrm{Me}$ subí a la ácida montaña," "Trepé las peñas con el venado" y" 'Subí derecho a la montaña". Ahora, en cambio, usa una forma compuesta, dilatoria e indicio del mayor esfuer-

15 Cito por The Complete Tales and Poems of Edgar Allan Poe (New York: The Modern Library, 1938).

16 Gaston Bachelard, El aire y los sueños (México: Breviarios, FCE, 1958). 
zo: "Me fui ganando la montaña."

No sólo el ascenso en sí, el viaje en su totalidad tiene mayores peligros, los que se asocian con el mitema de la aventura de la noche:

Me fui ganando la montaña, ahora negra como Medea,

sin tajada de resplandores, como una gruta vaga y cierta.

La imagen corresponde evidentemente al viaje de la noche, que es equivalente al descenso de los infiernos en la aventura mítica. La iniciante se adentra en el mundo de la oscuridad en el cual todo se da para que se pierda. Aun la mención de la "gruta vaga" la relaciona con el laberinto y lejanamente con la búsqueda de Dédalo en el laberinto cretiano. La expresión "cierta" sin embargo entreabre la esperanza de que en ese mundo va a encontrar lo que busca, la cercanía de lo numinoso. Por eso, no sorprenden los rasgos especiales, lo excepcional de las nuevas flores:

Ellas no estaban en las ramas

ellas no abrian en las piedras. (vv. 53-54)

Las flores que ahora busca se aproximan al elixir mágico. De allí viene su carácter excepcional. Existen, están allí en el lugar excepcional, en el espacio que posee el máximo de virtudes positivas en la poética de la verticalidad. Al llegar a la culminación de la aventura, al final del camino de las pruebas, se abre el espacio en que se encuentra lo mágico, lo maravilloso. La hablante recurre entonces a la ternura y suavidad para describir sus acciones:

Y las corté del aire dulce tijereándolo ligero.

Acción que la transforma en segadora maravillada, con lo cual el poema se desplaza hacia las hierofanías agrícolas. Mircea Eliade ha destacado bien el carácter mítico religioso del acto de segar: 17

La recolección es un ritual que se efectúa en condiciones de pureza ceremonial, con oraciones y sacrificios que suponen ciertos peligros, etc. No se trata pura y simplemente de coger una planta, cierta especie botánica, sino de repetir una acción primordial (es la divinidad la que cogió por primera vez) para obtener una sustancia saturada de sacralidad, variante menor del árbol de la vida, fuente de toda curación. (pp. 272-273)

La segadora, llena de entusiasmo y plenitud, ha llegado a la tierra prometida, a la zona sagrada en que se encuentra el elíxir. Es el país de la abundancia. Es la plenitud de la creación y de la naturaleza. Aun más, es una vidente ciega: "como si fuese/la cortadora que está ciega." Su valor y fuerza es interior, por ello no necesita de la vista.

Cuando ha logrado posesionarse del anhelado trofeo, vuelve una vez más hacia quien la envió:

17 Mircea Eliade, Tratado de bistoria de las religiones (México: Ediciones Era, 1964). 
Cuando la misión del héroe se ha llevado a cabo, por penetración en la fuente de poder o por medio de la gracia de alguna personificación masculina o femenina, humana o animal, el aventurero debe regresar con su trofeo transmutador de la vida. (Campbell, El héroe de las mil caras, p. 179)

Por ello, debe regresar al "reino de la humanidad, donde la dádiva habrá de significar la renovación de la comunidad, de la nación, del planeta o de los diez mil mundos." (Campbell, p. 179)

El regreso implica el descenso de la montaña y el encuentro con el mundo, el que ha de cambiar necesariamente por la influencia del héroe que ha vencido el camino de las pruebas. No sorprende, entonces, que la hablante se refiere expresamente a la "diosa" y haga resaltar el cambio que se ha operado en ella. Ya no es estática ni se encuentra limitada en el centro de la pradera. Es ahora un ser dinámico, "ahora ella caminaba", y concluye la estrofa con una extraña frase: "Ya no era blanca ni violenta." Rasgos que antes no había nombrado. Esta última caracterización revela retrospectivamente un aspecto de la relación entre la hablante y la diosa. Esta no se había comportado cariñosa ni bondadosamente. La mención de "sierva" no había sido azarosa, sino que revelaba la real relación. Era un indicio de su actitud despótica, de diosa cruel que exige sacrificios a sus servidores.

A hora en cambio, junto con su adquirido dinamismo, con su nueva libertad, pierde conciencia de sí misma.

Ella se iba, la sonámbula, abandonando la pradera, y yo siguiéndola y siguiéndola por el pastal y la alameda. (yv. 65-68)

Las estrofas XVII, XVIII y XIX manifiestan la iniciación lograda. La protagonista ha pasado a ser discipula, silenciosa y fiel de la diosa. Aún más, ha llevado a cabo una aventura que no sólo la inicia a ella sino que además libera a la sacerdotisa. Hay dos matices significativos. El abandono de la pradera y su sustitución, como habitas, por el pastaly la alameda. A la vez, se produce un cambio en la misma diosa, ya calificada como sonámbula y ahora descrita:

\section{Ella delante va sin cara; \\ ella delante va sin huella.}

Esta imagen surrealista parece proyectar al plano mítico al personaje a quien la protagonista sirve.

El proceso mitificador en el poema es admirable y sorprende descubrir la serie de relaciones, conscientes o inconscientes, en la imaginación mistraliana. Lo que comienza simplemente "gobernadora" y que luego llama "reina" se enriquece y explica más al llegar a estos versos. Se la asocia cada vez más con la imagen del ánima de que habla Jung o la Dama de la Casa del Sueño a que alude Campbell en el párrafo citado al comienzo del ensayo.

La expresión "sin cara" remite aun más al personaje al mundo del mito, del anonimato universal, a la divinidad que se acerca a la diosa sin rostro. Por lo tanto, aun más pura en su simbolismo de perfección el "sin huella" alude una vez más a la 
espiritualización.

La función de la hablante es servirla, a modo de sacerdotisa o eterna segadora. Su vida no es sino servir a la diosa. El encuentro de la primera estrofa la ha conducido a sacrificar toda su existencia a lo que representa la extraña diosa, cuya oferta cotidiana, cuyo tributo vivificante, son las flores del aire. El simbolismo del aire, en la interpretación recogida por Cirlot, funde los tres planos que hemos querido integrar en nuestro análisis:

El aire se asocia esencialmente con tres factores: el hálito vital, creador y, en consecuencia, la palabra; el viento de la tempestad, ligado en muchas mitologías a la idea de la creación; finalmente, al espacio como ámbito de movimiento y de producción de procesos vitales. La luz, el vuelo, la ligereza, así como también el perfume y el olor son elementos en conexión con el simbolismo general del aire. (Cirlot, Dicc, p. 76)

El título del poema La flor del aire, por lo tanto, no es azaroso en el plano de la imaginación mitificadora. El aire es lo creador, especialmente la palabra. La diosa a quien la hablante ha querido servir ha adquirido la libertad y se realiza cuando se le ofrenda la perfección de la palabra, la poesía.

La estrofa final es la última confesión. La iniciada, ya sacerdotisa de esta religión, ha de dedicar toda su vida, hasta "cuando mi tiempo se disuelva", a ofrendar los poemas-"la flor del aire"- a la divinidad, divinidad al parecer insaciable. 